\title{
CULTIVATION OF GERBERA IRRIGATED WITH TREATED PETROLEUM REFINERY WASTEWATER
}

\author{
Soliman, E. M. ${ }^{(1)}$; El-azab, W. I. M. ${ }^{(2)}$ and Ali, N. ${ }^{(3)}$
}

1) Department of agricultural science, Institute of Environmental Studies and Research, Ain Shams University 2) Egyptian Petroleum Research Institute, Analysis and Evaluation Department 3) Petroleum Gases Co. HSE Department

\begin{abstract}
A detailed evaluation for the use of treated petroleum refinery wastewater in irrigation of Gerbera plants, vegetative growth, production and chemical compounds of Gerbera jamesonii were determined. The experiment was conducted for two successive seasons of 2014 and 2015 at the Floriculture Nursery under full sunlight conditions at Horticulture Research Institute, Ornamental Plants and Landscape Gardining Research Department, Egypt using clay loam soil and $30 \mathrm{~cm}$ pots. The mean plant height in harvest was $32.33+1.86$ and $25.67+2.18 \mathrm{~cm}$ for irrigation with treated wastewater at the first and second seasons respectively. Mean number of roots /plant in harvest was $42.33+5.5$ and $42.67+2.03$ for irrigation with treated wastewater at the first and second seasons respectively. Mean flowers number / plant in harvest were $6.42+1.1$ and $6.81+1.3$ for irrigation with treated wastewater at the first and second seasons respectively. Mean flower diameters in harvest were $7.44+1.14$ and $7.1+1.18 \mathrm{~cm}$ for irrigation with treated wastewater at the first and second seasons respectively. The mean numbers of leaves / plant in harvest were $8.33+0.37$ and $6.0+1.0$ for irrigation with treated wastewater at the first and second seasons respectively.
\end{abstract}

Keywords: Water reuse, Treated petroleum refinery wastewater effluent, Gerbera, Fertigation, Floriculture.

\section{INTRODUCTION}

Water is an important resource, vital for both social and economic growth (Soliman et al., 2012; Dobson, and Burgess, 2007). 
Egypt's water resources are limited to the Nile River, deep groundwater in the Delta, the Western Deserts, and Sinai, sporadic rainfall and flash floods The overall efficiency of the Nile system in Egypt is about 75\%.The actual resources currently available for use in Egypt are 55.5 BCM/year and 1.0 $\mathrm{BCM} / \mathrm{year}$ effective rainfall on the northern strip of the Delta, non-renewable groundwater for western desert and Sinai (Abdin and Gafaar, 2009). While water requirements for different sectors in Egypt are in the order of 75 $\mathrm{BCM} / \mathrm{year}$ and therefore, the gap between the needs and availability of water is about $20 \mathrm{BCM} / \mathrm{year}$. This gap is overcome by water recycling and possible desalination of sea water.

The reuse of treated industrial wastewater called non-conventional source is necessary to meet a part of the water requirements. For petrochemical and petroleum refinery industries, Wastewater generated is 0.4 to 1.6 times of crude oil processed (Ishak et al., 2012).

A typical refinery effluent treatment plant consists of two basic treatment stages. The first stage consists of mechanical and physicochemical treatments followed by the biological treatment of the pre-treated primary effluent. Treated effluents may be used in agriculture as a source of water and nutrients for plants especially cut flower crops. (Friedman et al., 2007 and Papadopoulos et al., 2005).

Gerbera, commercially grown throughout the world in a wide range of climatic conditions. (Sujatha et al., 2002). Gerbera belongs to the family Asteraceae (Cardoso and Silva, 2013). Gerbera comprises 45 species, native to tropical Asia and Africa (Keditsu R. 2013). Gerbera was grouped into 
single, semi-double and double cultivars based on flower heads (Loser 1986). Gerbera species bear a large capitulum with striking, two-lipped ray florets in yellow, orange, white, pink or red colors.

Gerbera sp. May have many medicinal uses. (Nungki et al. 2015 and Srivastava et al. 2009).

Gerbera is very popular and widely used as a decorative garden plant or as cut flowers. It is the fifth most used cut flower in the world. It is also used as a model for studying flower formation (Dos Santos et al. 2015).There is still very little information concerning the use of treated wastewater for irrigation and fertigation; mainly for growing gerbera and cut flower species. Darwish et al. 1999 demonstrated that greenhouse crops might be excellent options when associated with the reuse of treated domestic wastewater. On the other hand, there is no information about using treated industrial effluents especially petroleum refinery wastewater for gerbera cultivation. The present work focuses on the technical feasibility regarding the use of treated industrial effluents for the growing gerbera considering the nutritional effects on growth variables, yield and flower quality. Cairo Oil Refinery Company (CORC) is one of the biggest petrochemical companies in Egypt and refines about $25 \%$ of refining capacity in Egypt; the treated wastewater of Mostorod plant was used in this investigation to study its effect on Gerbera growth.

\section{MATERIALS AND METHODS}

This investigation was carried out at the Floriculture Nursery under full sunlight conditions in the Agricultural Research Institute, Horticulture Research Institute, Ornamental Plants and Landscape Gardining Research 
Department, Giza, Egyp during two successive seasons of 2014 and 2015 to detrmine the effect of using different water resources (petroleum refineray treated wastewater, Nile water and tap water ) on Gerbera seading

Soil analysis: Soil used during the experiment was analyzed to determine its physical and chemical properties in the experiment. The used soil is brownish black loam (clay loam) obtained from Nile Delta (Qalubia governerate). The soil samples were air-dried, crushed and finely ground then sieved through (2 mm). Mechanical analysis was estimated according to Jackson (1973).

$\mathrm{pH}$ values were measured in the suspension according to ASTM D 4972 by using benchtop pH/ISE meters, ORION model 710A. EC was measured at $25^{\circ} \mathrm{C}$ using ATC bench electric conductivity meters, HANNA, Model HI 8820 .

Soluble cations and anions were determined in the extract of soil paste as described by Black (1982) using Ion Chromatography (IC) model DX-500 Chromatography. While carbonates (CO3) and bicarbonates (HCO3) were detected by titration method using $0.1 \mathrm{~N} \mathrm{HCl}$.

Organic matter: Organic matter is measured using DR-2000 spectrophotometer instrument $\mathrm{HACH}$, where organic matter is oxidized under standardized conditions with potassium dichromate in sulphuric acid solution as reported by Baruah and Barthakur (1997).

Wastewater Samples location, collection, and preparation: The treated industrial wastewater effluent used in the study was obtained from drainage line of Wastewater Treatment unit of Cairo Oil Refining Co on Ismailia Channel, Mostorod Cairo. For compression, water samples from Ismailia 
Channel were collected (100 m upstream) and tap water samples also were used for analysis and characterization.

Sampling. Water samples were collected from Ismailia Canal, according to methods stated in Standard Methods for Examination of Water and Wastewater, (20th Ed.), (APHA 1998).

Physical properties: The $\mathrm{pH}$ of the samples was determined using the electrometric method according to ASTM D1293 using a digital $\mathrm{pH}$ meter model Hana $\mathrm{pH}$ 213. The density and specific gravity were determined according to ASTM D 1429. Electrical conductivity \& resistivity were determined according to ASTM D 1125 using digital conductivity meter WTW model Cond. 330I .

Total dissolved solids were determined according to ASTM D 5907. The salinity of samples was calculated from chloride content. The alkalinity of samples was determined by titration according to ASTM D 1067 using a digital $\mathrm{pH}$ meter model Hana $\mathrm{pH}$ 213.Total hardness of samples was calculated according to method ASTM D 1126.

Anions and cations were determined according to ASTM D 4327 and 6919, respectively using ion chromatography Dionex IC model ICS 1100 equipped with high capacity columns (AS9 and CS12) for anion and cations, respectively.Heavy metals were determined using Flame Atomic Absorption Spectrophotometer model Zenit 700p according to ASTM D 4691.

Sodium absorption ratio (SAR) was calculated according to the following equation: 
$\mathrm{SAR}=[\mathrm{Na}] / \sqrt{[C a]+[M g] / 2}$

Where $\mathrm{Na}, \mathrm{Ca}, \mathrm{Mg}$ is expressed in milliequivalents/liter

Basic ratio (BR) value can be estimated according to the following equation:

$\mathrm{BR}=[\mathrm{Na}]+[\mathrm{K}] /[\mathrm{Ca}]+[\mathrm{Mg}]$

Where $\mathrm{Na}, \mathrm{K}, \mathrm{Ca}, \mathrm{Mg}$ are expressed in milliequivalents/liter

The residual sodium carbonate (RSC) index is used to indicate the alkalinity hazard for soil.

$\mathrm{RSC}$ index $=[\mathrm{HCO} 3+\mathrm{CO} 3]-[\mathrm{Ca}+\mathrm{Mg}]$ are expressed in milliequivalents/liter

The experiment was conducted at the Floriculture Nursery under full sunlight conditions A hole was drilled at the bottom of the pot, and a $2 \mathrm{~cm}$ layer of crushed stone was deposited and covered with geotextile mesh, after which a $30 \mathrm{~cm}$ layer, (4 kg) of a brownish black loam was added.

Six months Gerbera seedlings Gerbera jamesonii), local variety type were obtained from Horticulture Research Institute, Ornamental Plants and Landscape Gardining Research Department (the local variety with orange flowers) planted in $30 \mathrm{~cm}$ clay pots, irrigation with different water types used (treated waste water, Nile water and tap water), after 20 weeks data were recorded on growth performance the following vegtative growth parameters

The plant height was measured in centimeters from the soil surface to the highest point of the plant. Number of leaves / plant were counted for each plant for all traetmentss, the average was clculated and recorded.Number of flowers per plant was obtained for each plant the average was calculated and recorded.Flower diamter was measured in centimeter at the full opening 
stage. The average was calculated and recorded.The stem diamter was measured in centimeter in the soil surface in the pot using a caliper.

Chemical analysis: Total soluble indoles were determined using colorimetric method (A. O. A. C, 1990) using the standard curve of indole acetic acid.

Total soluble phenols were determined by using folin-denis colorimetric method (A. O. A. C, 1990), a standard curve of pyrogallol.

Total carbohydrates content was determined in dry leaf powder.

Total chlorophylls were determined in leaf samples (mg/100g FW) by using colorimetric method (A.O.A.C, 1990).

Statistical analysis: Experimental design was laid out in a completely random experimental design with three treatments and nine replications. The treatments consisted of application of different types of water (treated wastewter, Nile water and tap water in black soil). each traetment included 9 plants per treatment. All data collected were subjected to statistical analysis of variance as described by Gomez and Gomez (1984). The treatment means were compred using L.S.D test at 0.05 level of probability.

\section{RESULTS AND DISCUSSION}

Water analysis results: The study of the treated petroleum refineary wastewater effluent for reuse began with the characterization of the main effluents. The average results of analysis are listed in the table (1).From the measured date during the different agricultural seasons, it was found that the composition of the different types of water is nearly similar from the mineral composition. The largest dissolved solids content was found in the treated refinery waste water then the upstream Nile water then the tap water which is 
considered as the lowest mineral concentration. The overall concentration is accepted according to law 48 of 1982 for the protection of the Nile river and its waterways from pollution $\mathrm{pH}$ within the range $7-8.5$, organic Nitrogen not to exceed $1 \mathrm{mg} / \mathrm{l}$, Ammonia not to exceed $0.5 \mathrm{mg} / \mathrm{l}$, oils and grease not to exceed $0.1 \mathrm{mg} / \mathrm{l}$, total alkalinity within the range $20-150 \mathrm{mg} / \mathrm{l}$, sulphate not to exceed $200 \mathrm{mg} / \mathrm{l}$, Iron not to exceed $1 \mathrm{mg} / \mathrm{l}$ Manganese not to exceed 0.5 $\mathrm{mg} / \mathrm{l}$, Copper not to exceed $1 \mathrm{mg} / \mathrm{l}$. The organic content is totally different between the used water samples since the treated wastewater contains a higher organic content giving higher COD and BOD values, higher oil and phenol content over the accepted ranges for BOD not to exceed $6 \mathrm{mg} / \mathrm{l}$, for COD not to exceed $10 \mathrm{mg} / \mathrm{l}$. For more characterization, a detailed study for the most dangerous pollutant 16 polyaromatic compounds was examined separately, and the found values are listed in Table (2) From the obtained data in Table (2) it was found that the treated wastewater is contaminated with a higher level of PAH compared to the Nile river water with a total of 5.08 ppm. 
Table (1): Analysis of the different irrigation water used in the study all determinations are given as ranges in $\mathrm{mg} / \mathrm{l}$ or as specified.

\begin{tabular}{|c|c|c|c|}
\hline Analysis & $\begin{array}{c}\text { CORC Treated } \\
\text { wastewater }\end{array}$ & $\begin{array}{c}\text { Nile } \\
\text { river water }\end{array}$ & Tap water \\
\hline T.D.S mg/l & $501.1 \pm 240.81$ & $352.5 \pm 31.24$ & $320 \pm 21.54$ \\
\hline $\begin{array}{c}\text { E.C. } \mu \mathrm{s} / \mathrm{cm} @ \\
25 \mathrm{oC}\end{array}$ & $589 \pm 27$ & $445 \pm 33.81$ & $440 \pm 29.61$ \\
\hline Salinity $\mathrm{mg} / \mathrm{l}$ & $105.1 \pm 40.31$ & $100.7 \pm 11.18$ & $61.38 \pm 9.38$ \\
\hline Hardness mg/l & $145.3 \pm 51.69$ & $161.9 \pm 18.35$ & $144.15 \pm 13.58$ \\
\hline pH@ 25oC & $7.84 \pm 0.50$ & $7.14 \pm 0.09$ & $7.60 \pm 0.19$ \\
\hline BOD mg/l & $89.15 \pm 22.33$ & $58.55 \pm 12.44$ & $18.15 \pm 2.37$ \\
\hline COD mg/l & $206.98 \pm 20.40$ & $89.74 \pm 34.19$ & $39.34 \pm 3.45$ \\
\hline Lithium mg/l & $0.039 \pm 0.01$ & $0.0033 \pm 0.001$ & $0.0035 \pm 0.002$ \\
\hline Sodium mg/l & $84.60 \pm 18.51$ & $39.00 \pm 10.60$ & $28.58 \pm 9.75$ \\
\hline Potassium mg/l & $7.10 \pm 0.96$ & $6.95 \pm 0.68$ & $5.603 \pm 0.54$ \\
\hline Magnesium mg/l & $10.20 \pm 4.27$ & $13.10 \pm 2.88$ & $12.08 \pm 2.53$ \\
\hline Calcium mg/l & $41.35 \pm 13.32$ & $43.25 \pm 13.49$ & $37.9 \pm 12.51$ \\
\hline Fluoride $\mathrm{mg} / \mathrm{l}$ & $0.565 \pm 0.06$ & $0.66 \pm 0.05$ & $0.65 \pm 0.15$ \\
\hline Chloride $\mathrm{mg} / \mathrm{l}$ & $63.7 \pm 14.26$ & $61 \pm 18.22$ & $37.2 \pm 12.13$ \\
\hline Bromide $\mathrm{mg} / \mathrm{l}$ & $0.0145 \pm 0.001$ & $0.039 \pm 0.06$ & $0.04 \pm 0.01$ \\
\hline Nitrate $\mathrm{mg} / \mathrm{l}$ & $0.18 \pm 0.006$ & $1.374 \pm 0.16$ & $4.64 \pm 0.11$ \\
\hline Hydroxide mg/l & ND & $\mathrm{ND}$ & ND \\
\hline Carbonate $\mathrm{mg} / \mathrm{l}$ & ND & ND & ND \\
\hline Bicarbonate mg/l & $272 \pm 12.95$ & $160 \pm 13.68$ & $136 \pm 15.30$ \\
\hline Sulfate $\mathrm{mg} / \mathrm{l}$ & $20.5 \pm 2.80$ & $27.1 \pm 4.60$ & $38.34 \pm 3.66$ \\
\hline Phosphate mg/l & $2.565 \pm 1.72$ & $2.356 \pm 1.62$ & $0.18 \pm 0.12$ \\
\hline TPH, mg/l & $10.65 \pm 3.83$ & $2.20 \pm 0.85$ & Nil \\
\hline Phenol, mg/l & $7.20 \pm 0.77$ & $1.89 \pm 0.18$ & $0.18 \pm 0.08$ \\
\hline
\end{tabular}

$\mathrm{ND}=$ Not detectable . 
J. Environ. Sci.

Institute of Environmental Studies and Research - Ain Shams University

Table(2): Characteristics of 16 PAHs of irrigation water

\begin{tabular}{|c|c|c|c|c|}
\hline \multicolumn{2}{|c|}{16 PAHs (mg/l) } & \multirow{2}{*}{$\begin{array}{c}\begin{array}{c}\text { CORC } \\
\text { Treated } \\
\text { wastewater }\end{array} \\
2.69 \pm 2.18\end{array}$} & \multirow{2}{*}{$\begin{array}{c}\begin{array}{c}\text { Nile } \\
\text { river water }\end{array} \\
0.31 \pm 0.18\end{array}$} & \multirow{2}{*}{$\frac{\text { Tap Water }}{\text { N.D }}$} \\
\hline $\begin{array}{c}2- \\
\text { Ring }\end{array}$ & Naphthalene & & & \\
\hline \multicolumn{2}{|r|}{ Total (2-Ring) } & $2.69 \pm 2.18$ & $0.31 \pm 0.18$ & N.D \\
\hline \multirow{5}{*}{$\begin{array}{c}3- \\
\text { Ring }\end{array}$} & Acenaphthylene & $0.11 \pm 0.10$ & N.D & N.D \\
\hline & Acenaphthene & $0.45 \pm 0.30$ & $0.26 \pm 0.02$ & N.D \\
\hline & Fluorene & $0.07 \pm 0.02$ & $0.12 \pm 0.01$ & N.D \\
\hline & Phenanthrene & $0.03 \pm 0.01$ & $0.031 \pm 0.15$ & N.D \\
\hline & Anthracene & $0.03 \pm 0.01$ & $0.087 \pm 0.02$ & N.D \\
\hline \multicolumn{2}{|r|}{ Total (3-Ring) } & $0.69 \pm 0.44$ & $0.498 \pm 0.2$ & N.D \\
\hline \multirow{4}{*}{$\begin{array}{c}4- \\
\text { Ring }\end{array}$} & Fluoranthene & $0.07 \pm 0.08$ & N.D & N.D \\
\hline & Pyrene & $0.63 \pm 0.17$ & N.D & N.D \\
\hline & Benzo[a]anthracene & $0.04 \pm 0.02$ & N.D & N.D \\
\hline & Chrysene & $0.61 \pm 0.10$ & N.D & N.D \\
\hline \multicolumn{2}{|r|}{ Total (4-Ring) } & $1.35 \pm 0.37$ & $0.037 \pm 0.016$ & N.D \\
\hline \multirow{4}{*}{$\begin{array}{c}5- \\
\text { Ring }\end{array}$} & Benzo[b]fluoranthene & $0.30 \pm 0.07$ & N.D & N.D \\
\hline & Benzo[k]fluoranthene & $0.02 \pm 0.01$ & N.D & N.D \\
\hline & Benzo[a]pyrene & $0.03 \pm 0.01$ & N.D & N.D \\
\hline & Dibenz[a,h]anthracene & N.D. & N.D & N.D \\
\hline \multicolumn{2}{|r|}{ Total (5-Ring) } & $0.35 \pm 0.09$ & $0.05 \pm 0.01$ & N.D \\
\hline \multirow[b]{2}{*}{$\begin{array}{c}\text { 6- } \\
\text { Ring }\end{array}$} & Benzo[ghi]perylene & N.D. & N.D & N.D \\
\hline & $\begin{array}{c}\text { Indeno[1,2,3- } \\
\text { cd]pyrene }\end{array}$ & N.D. & N.D & N.D \\
\hline \multicolumn{2}{|r|}{ Total (6-Ring) } & N.D. & N.D & N.D \\
\hline \multicolumn{2}{|r|}{ Total 16 PAHs } & $5.08 \pm 3.08$ & $0.895 \pm 0.406$ & N.D \\
\hline
\end{tabular}

$\mathrm{ND}=$ Not detectable.

The soil in the experiment was a clay loamy soil. The physical and chemical characteristics of the soil were shown in Tables $(3 \& 4)$. 
Table(3): Mechanical analysis of the experimental soil.

\begin{tabular}{|c|c|c|c|}
\hline \multirow{2}{*}{ Parameters } & \multirow{2}{*}{ Unit } & \multicolumn{2}{|c|}{ Seasons } \\
\cline { 3 - 4 } & & $\mathbf{2 0 1 4}$ & $\mathbf{2 0 1 5}$ \\
\hline \hline Sand & $\%$ & 38.80 & 37.75 \\
\hline Silt & $\%$ & 32.92 & 33.10 \\
\hline Clay & $\%$ & 28.28 & 29.15 \\
\hline Textural class & ------ & Clay loam & Clay loam \\
\hline
\end{tabular}

The chemical composition of the soil was studied before irrigation with different waters and after the two agricultural seasons. The tests were repeated to find out the effect of irrigation water on the constituents of soil. Data are listed in Table (4). According to the obtained data, it was found that the chemical composition was changed approximately and the measured indices like SAR and RSC showed that the soil has a better criteria. 
J. Environ. Sci.

Institute of Environmental Studies and Research - Ain Shams University

Table(4): Characteristics of Soil before and after irrigation.

\begin{tabular}{|c|c|c|c|c|c|c|}
\hline \multirow[t]{2}{*}{ Determinations } & \multicolumn{2}{|c|}{$\begin{array}{c}\text { CORC Treated } \\
\text { wastewater }\end{array}$} & \multicolumn{2}{|c|}{$\begin{array}{c}\text { Nile } \\
\text { river water }\end{array}$} & \multicolumn{2}{|c|}{ Tap water } \\
\hline & Before & After & Before & After & Before & After \\
\hline $\mathrm{pH}$ & $\begin{array}{l}8.05 \pm \\
0.45\end{array}$ & $\begin{array}{c}8.02 \pm \\
0.30\end{array}$ & $\begin{array}{l}8.22 \pm \\
0.25\end{array}$ & $\begin{array}{c}8.02 \pm \\
0.50\end{array}$ & $\begin{array}{c}8.04 \pm \\
0.4\end{array}$ & $\begin{array}{c}8.08 \pm \\
0.35\end{array}$ \\
\hline $\begin{array}{l}\text { E.C. } \mathrm{d} / \mathrm{m} \\
\text { @ } 25 \mathrm{oC} \\
\end{array}$ & $\begin{array}{l}0.722 \pm \\
0.033 \\
\end{array}$ & $\begin{array}{c}0.482 \pm \\
0.024 \\
\end{array}$ & $\begin{array}{c}0.319 \pm \\
0.035 \\
\end{array}$ & $\begin{array}{c}0.628 \pm \\
0.023 \\
\end{array}$ & $\begin{array}{c}0.650 \pm \\
0.025 \\
\end{array}$ & $\begin{array}{l}0.628 \pm \\
0.018 \\
\end{array}$ \\
\hline Sodium mg/l & $\begin{array}{c}110 \pm \\
12.2\end{array}$ & $80 \pm 7.25$ & $50 \pm 6.25$ & $\begin{array}{l}109 \pm \\
12.25\end{array}$ & $\begin{array}{l}98 \pm \\
15.3 \\
\end{array}$ & $\begin{array}{l}99 \pm \\
9.65\end{array}$ \\
\hline $\begin{array}{c}\text { Potassium } \\
\mathrm{mg} / \mathrm{l}\end{array}$ & $\begin{array}{l}13 \pm \\
2.25 \\
\end{array}$ & $11 \pm 2.84$ & $7 \pm 1.24$ & $13 \pm 3.15$ & $12 \pm 3.0$ & $\begin{array}{l}12 \pm \\
2.45 \\
\end{array}$ \\
\hline $\begin{array}{l}\text { Magnesium } \\
\mathrm{mg} / \mathrm{l}\end{array}$ & $8.1 \pm 2.24$ & $6.2 \pm 1.2$ & $4.1 \pm 1.25$ & $8.2 \pm 2.3$ & $6.9 \pm 2.2$ & $7.4 \pm 2.46$ \\
\hline $\begin{array}{c}\text { Calcium } \\
\mathrm{mg} / \mathrm{l}\end{array}$ & $23.1 \pm 4.8$ & $18.1 \pm 3.6$ & $12.2 \pm 1.8$ & $\begin{array}{r}23.2 \\
\pm 5.7\end{array}$ & $20.9 \pm 6.8$ & $21.8 \pm 3.4$ \\
\hline $\begin{array}{c}\text { Chloride } \\
\mathrm{mg} / \mathrm{l}\end{array}$ & $\begin{array}{l}195 \pm \\
26.6 \\
\end{array}$ & $\begin{array}{l}130 \pm \\
16.4\end{array}$ & $\begin{array}{l}73 \pm \\
6.44\end{array}$ & $\begin{array}{c}169 \pm \\
28.6\end{array}$ & $\begin{array}{c}188 \pm \\
36.8\end{array}$ & $\begin{array}{c}175 \pm \\
16.8\end{array}$ \\
\hline Nitrate mg/l & $\begin{array}{c}10.7 \pm \\
2.2\end{array}$ & $5.4 \pm 1.2$ & $7.2 \pm 1.6$ & $4.9 \pm 2.1$ & $11.2 \pm 2.4$ & $7.2 \pm 2.6$ \\
\hline Carbonate $\mathrm{mg} / \mathrm{l}$ & N.D & N.D & N.D & N.D & N.D & N.D \\
\hline $\begin{array}{c}\text { Bicarbonate } \\
\mathrm{mg} / \mathrm{l}\end{array}$ & $74 \pm 16.0$ & $69 \pm 14.0$ & $66 \pm 12.0$ & $\begin{array}{l}79 \pm \\
15.0\end{array}$ & $115 \pm 25.0$ & $72 \pm 13.0$ \\
\hline Phosphate mg/l & $\begin{array}{l}10.6 \\
\pm 1.4 \\
\end{array}$ & $\begin{array}{c}10.5 \pm \\
0.92\end{array}$ & $8.7 \pm 0.83$ & $\begin{array}{c}11.3 \pm \\
1.42 \\
\end{array}$ & $9.5 \pm 1.2$ & $\begin{array}{c}12.2 \pm \\
0.94 \\
\end{array}$ \\
\hline $\begin{array}{c}\text { Organic Matter } \\
\%\end{array}$ & $\begin{array}{c}1.88 \pm \\
0.18\end{array}$ & $\begin{array}{c}1.61 \pm \\
0.12\end{array}$ & $\begin{array}{c}2.89 \pm \\
0.68\end{array}$ & $\begin{array}{l}1.92 \pm \\
1.08\end{array}$ & $2.53 \pm 1.1$ & $\begin{array}{c}1.83 \pm \\
0.58\end{array}$ \\
\hline (SAR) & 4.96 & 4.09 & 3.13 & 4.90 & 4.70 & 4.62 \\
\hline (BR) & 5.57 & 5.27 & 4.92 & 5.48 & 5.61 & 5.38 \\
\hline (RSCI) & -0.617 & -0.291 & 0.130 & -0.548 & 0.265 & -0.526 \\
\hline
\end{tabular}


Table(5): Effect of different water types on vegetative growth of Gerbera jamesonii during 2014 and 2015 seasons

\begin{tabular}{|c|c|c|c|c|c|}
\hline \multirow[b]{2}{*}{ Characters } & \multirow[b]{2}{*}{ Season } & \multicolumn{3}{|c|}{ Water source } & \multirow[b]{2}{*}{ LSD } \\
\hline & & $\begin{array}{c}\text { Treated } \\
\text { wastewater }\end{array}$ & $\begin{array}{c}\text { Nile } \\
\text { river water }\end{array}$ & Tap water & \\
\hline \multirow{2}{*}{$\begin{array}{l}\text { Mean Plant } \\
\text { height }(\mathrm{cm})\end{array}$} & First & $32.33 \pm 1.86$ & $30.67 \pm 1.86$ & $28.67 \pm 1.76$ & NS \\
\hline & Second & $25.67 \pm 3.18$ & $28.67 \pm 3.17$ & $31.67 \pm 1.33$ & NS \\
\hline \multirow{2}{*}{$\begin{array}{c}\text { Mean Number } \\
\text { of leaves in } \\
\text { harvest }\end{array}$} & First & $8.33 \pm 0.33$ & $8.67 \pm 1.20$ & $7.33 \pm 0.33$ & NS \\
\hline & Second & $6.0 \pm 1.0$ & $9.67 \pm 1.86$ & $6.0 \pm 1.53$ & NS \\
\hline \multirow{2}{*}{$\begin{array}{c}\text { Mean Root } \\
\text { length in } \\
\text { harvest }(\mathrm{cm} .)\end{array}$} & First & $40.67 \pm 2.33$ & $38.67 \pm 1.76$ & $28.67 \pm 1.76$ & 6.82 \\
\hline & Second & $34.67 \pm 7.64$ & $30.33 \pm 4.18$ & $30.67 \pm 1.2$ & NS \\
\hline \multirow{2}{*}{$\begin{array}{c}\text { Mean Number } \\
\text { of Roots in } \\
\text { harvest }\end{array}$} & First & $42.33 \pm 5.5$ & $37.33 \pm 4.9$ & $39.33 \pm 3.9$ & NS \\
\hline & Second & $42.67 \pm 2.03$ & $47.0 \pm 4.3$ & $41.33 \pm 7.8$ & NS \\
\hline \multirow{2}{*}{$\begin{array}{c}\text { Mean fresh } \\
\text { weight of } \\
\text { leaves in } \\
\text { harvest(gm.) }\end{array}$} & First & $20.68 \pm 0.71$ & $24.48 \pm 1.14$ & $18.74 \pm 2.44$ & NS \\
\hline & Second & $17.73 \pm 0.82$ & $22.21 \pm 2.8$ & $24.85 \pm 143$ & NS \\
\hline \multirow{2}{*}{$\begin{array}{c}\text { Mean dry } \\
\text { weight of leaves } \\
\text { in harvest(gm.) }\end{array}$} & First & $4.04 \pm 0.43$ & $6.22 \pm 0.73$ & $5.28 \pm 0.50$ & NS \\
\hline & Second & $4.16 \pm 0.33$ & $4.52 \pm 0.49$ & $5.78 \pm 1.96$ & $\mathrm{NS}$ \\
\hline \multirow{2}{*}{$\begin{array}{c}\text { Mean fresh } \\
\text { weight of roots } \\
\text { in harvest(gm.) }\end{array}$} & First & $33.37 \pm 3.25$ & $24.85 \pm 4.06$ & $29.32 \pm 5.26$ & NS \\
\hline & Second & $34.27 \pm 2.46$ & 23.622 .32 & $26.96 \pm 1.22$ & 7.2 \\
\hline \multirow{2}{*}{$\begin{array}{c}\text { Mean dry } \\
\text { weight of roots } \\
\text { in harvest(gm.) }\end{array}$} & First & $7.51 \pm 0.40$ & $4.52 \pm 0.58$ & $4.87 \pm 0.14$ & 1.45 \\
\hline & Second & $7.24 \pm 0.97$ & $5.61 \pm 1.01$ & $6.28 \pm 1.05$ & NS \\
\hline \multirow{2}{*}{$\begin{array}{c}\text { Mean flower } \\
\text { number in } \\
\text { harvest }\end{array}$} & First & $6.42 \pm 1.1$ & $7.01 \pm 0.99$ & $6.35 \pm 1.2$ & NS \\
\hline & Second & $6.81 \pm 1.3$ & $6.88 \pm 1.1$ & $6.21 \pm 1.1$ & $\mathrm{NS}$ \\
\hline \multirow{2}{*}{$\begin{array}{l}\text { Mean flower } \\
\text { diameter in } \\
\text { harvest }(\mathrm{cm} .)\end{array}$} & First & $7.44 \pm 1.14$ & $8.1 \pm 1.21$ & $7.2 \pm 1.25$ & NS \\
\hline & Second & $7.1 \pm 1.18$ & $7.98 \pm 1.22$ & $7.1 \pm 1.19$ & NS \\
\hline
\end{tabular}


Results presented in table (5) showed that mean values of Gerbera jamesonii height in 2014 and 2015 growing seasons were not affected significantly by using different water types of irrigation. The greatest value $(32.22+1.86 \mathrm{~cm})$ for the first season and was obtained when plants were irrigated with wastewater while as the lowest one was $(28.67 \pm 1.76 \mathrm{~cm})$ and obtained by irrigation with tap water. These data are in agreement with those obtained by Lisânea et al. (2010) who recorded that treated effluents may be used in agricultural as a source of water and nutrients for plants especially cut flowers.

Irrigation with different waters types had no significant effect on number of leaves / plant of Gerbera jamesonii. The highest value of mean number of leaves / plant was obtained from Nile river water $(8.67+1.20)$ and $(9.69+1.86)$ for the first and second seasons respectively. The lowest values of number of leaves /plant of Gerbera jamesonii were obtained from irrigation with tap water in two seasons. These results are confirmed with that suggested by Lisânea et al. (2008).

Results presented in table (4) showed that number of flowers/plant of gerbera jamesonii had no significant increase when plants irrigated with different water types. Irrigated plants with Nile water gave the highest mean value of number of flowers /plant in both seasons $(7.01+0.99)$ and $(6.88+$ 1.1) for first and second seasons respectively. While the lowest number of flowers /plant obtained by using tap water. The same trend was obtained in mean flower diameter, which was $(8.1+1.21)$ and $(7.98+1.22)$ for the first and second seasons respectively. The lowest flower diameter $(7.2+1.25)$ and 
$(7.1+1.19)$ for the first and second seasons respectively were obtained by irrigated plants with tap water.

Number of roots was not affected significantly with different water types of irrigation. Mean root length was the highest non-significantly when plants were irrigated with treated wastewater in both seasons $(40.67+2.33)$ and $(34.6+7.64)$ respectively. The data are in accordance with Lisânea et al. (2008)

Table (5) shows the effect of different water types on fresh and dry weight of leaves and roots of Gerbera jamesonii during 2014 and 2015 seasons. Plants irrigated with different water types had no significant differences in leaves fresh or dry weight.

The highest fresh weight of leaves was obtained by irrigated plants with Nile river water $(24.48+1.14)$ in first season and $(24.85+1.43)$ in the second season when irrigated by tap water respectively. The same trend was obtained with mean dry weight of leaves. The highest value was obtained with Nile river water $(6.22+0.73)$ for the first season and $(5.78+1.96)$ when irrigated with tap water for the second season respectively.

Mean weight of fresh roots (gm.) was not affected significantly in the first season when plants were irrigated with different water types. The highest fresh weight of roots was $(33.37+3.25)$ with treated wastewater. The highest fresh weight of roots significantly was obtained by irrigated plants with treated wastewater $(34.27+2.46)$ respectively. These results are in accordance with Das et al. (2012). The mean dry weight of roots showed significant difference on the first season where the highest dry weight was obtained when irrigated plants with treated wastewater $(7.51+0.40)$. There was no 
significant difference in the second season for dry weight of roots by using different water types. These data are in accordance with Lisânea. et al. (2010)

Table (6) show the effect of different water types on total soluble indoles content, total soluble phenols content and total carbohydrates content of Gerbera jamesonii during 2014 and 2015 seasons. The highest total soluble indoles were obtained by irrigated plants with treated wastewater $(2.03 \pm 0.03)$ in The first season and $(1.74 \pm 0.04)$ in the second season respectively. The same trend was obtained with total soluble phenols content. The highest was obtained with treated wastewater $(3.51 \pm 0.14)$ for the first season and $(2.75 \pm 0.10)$ for the second season respectively. There was a small significant difference in total soluble indoles content, total soluble phenols content during the two seasons between plants irrigated with different water types.

The highest value for carbohydrate content was obtained at the first season $(1.63 \pm 0.03)$ when irrigated with tap water while at the second season it was $(1.60 \pm 0.01)$. It was found that there were no significant differences in total carbohydrate content during the two seasons between plants irrigated with different water types. These results are in accordance with Mehraj et al. (2014). 
Table(6): Effect of different water types on total soluble indoles, total soluble phenols and total carbohydrates content, in Gerbera jamesonii leaves during 2014 and 2015 seasons

\begin{tabular}{|c|c|c|c|c|c||}
\hline \multirow{2}{*}{ Characters } & Season & $\begin{array}{c}\text { CORC } \\
\text { Treated } \\
\text { wastewater }\end{array}$ & $\begin{array}{c}\text { Nile } \\
\text { river water }\end{array}$ & Tap water & LSD \\
\cline { 3 - 6 } & First & $2.03 \pm 0.03$ & $1.69 \pm 0.04$ & $0.45 \pm 0.03$ & 1.458 \\
\hline $\begin{array}{c}\text { Total soluble } \\
\text { indoles content } \\
\text { (mg/100 gm of } \\
\text { dry sample) }\end{array}$ & Second & $1.74 \pm 0.04$ & $0.49 \pm 0.02$ & $0.53 \pm 0.03$ & 0.124 \\
\cline { 2 - 6 } $\begin{array}{c}\text { Total soluble } \\
\text { phenols content } \\
\text { (mg of gallic acid } \\
\text { /g of dry sample })\end{array}$ & First & $3.51 \pm 0.14$ & $1.92 \pm 0.08$ & $0.81 \pm 0.01$ & 0.415 \\
\cline { 2 - 6 } & Second & $2.75 \pm 0.10$ & $1.47 \pm 0.35$ & $1.08 \pm 0.02$ & 0.945 \\
\hline $\begin{array}{c}\text { Total } \\
\text { carbohydrates } \\
\text { content } \\
(\% \text { wt. })\end{array}$ & First & $1.40 \pm 0.10$ & $1.53 \pm 0.04$ & $1.63 \pm 0.03$ & NS \\
\cline { 2 - 6 } & Second & $1.58 \pm 0.04$ & $1.43 \pm 0.04$ & $1.60 \pm 0.01$ & NS \\
\hline
\end{tabular}

Table (7) show the effect of different water types on Chlorophyll a, Chlorophyll b content and total carotenoid of Gerbera jamesonii during 2014 and 2015 seasons. The highest Chlorophyll a was obtained by irrigated plants with Nile water $(11.47 \pm 1.24)$ in the first season and $(14.61 \pm 0.55)$ in the second season when irrigated with treated wastewater respectively. The same trend was obtained with Chlorophyll $b$ content. The highest value was obtained with treated wastewater $(4.12 \pm 0.12)$ for the first season and $(6.18 \pm$ 0.18) for the second season respectively. There was a small significant difference between them in Chlorophyll a \& b content, during the two seasons between plants irrigated with different water types. 
The highest value for total carotenoid, represented as Carotene was obtained at the first season $(5.73 \pm 0.71)$ when irrigated with Nile water while at the second season it was $(5.80 \pm 0.57)$, for irrigation with treated wastewater respectively. It was found that there were no significant differences in total carotenoid content during the second season between plants irrigated with different water while there was a slight difference in the first season.

Table(7): Effect of different water types on total carotenoids, chlorophyll a and b in Gerbera jamesonii leaves during 2014 and 2015 seasons

\begin{tabular}{|c|c|c|c|c|c|}
\hline \multirow[b]{2}{*}{ Characters } & \multirow[b]{2}{*}{ Season } & \multicolumn{3}{|c|}{ Water source } & \multirow[b]{2}{*}{ LSD } \\
\hline & & $\begin{array}{c}\text { CORC } \\
\text { Treated } \\
\text { wastewater }\end{array}$ & $\begin{array}{c}\text { Nile } \\
\text { river water }\end{array}$ & Tap water & \\
\hline \multirow{2}{*}{$\begin{array}{c}\begin{array}{c}\text { Chlorophyll a } \\
\text { content } \\
(\mathrm{mg} / 100 \mathrm{~g} \mathrm{FW})\end{array} \\
\end{array}$} & First & $5.39 \pm 0.32$ & $11.47 \pm 1.24$ & $8.73 \pm 0.23$ & 3.393 \\
\hline & Second & $14.61 \pm 0.55$ & $14.03 \pm 0.22$ & $9.98 \pm 0.09$ & 1.548 \\
\hline \multirow{2}{*}{$\begin{array}{l}\text { Chlorophyll b } \\
\text { Content } \\
(\mathrm{mg} / 100 \mathrm{~g} \mathrm{FW})\end{array}$} & First & $1.56 \pm 0.16$ & $4.12 \pm 0.12$ & $2.35 \pm 0.13$ & 0.636 \\
\hline & Second & $6.18 \pm 0.18$ & $3.14 \pm 0.05$ & $3.57 \pm 0.02$ & 0.481 \\
\hline \multirow{2}{*}{$\begin{array}{c}\text { Total } \\
\text { carotenoid, } \\
\text { Carotene } \\
(\mathrm{mg} / 100 \mathrm{~g} \mathrm{FW})\end{array}$} & First & $3.42 \pm 0.09$ & $5.73 \pm 0.71$ & $4.79 \pm 0.56$ & 2.16 \\
\hline & Second & $5.80 \pm 0.57$ & $5.40 \pm 0.49$ & $5.27 \pm 0.61$ & NS \\
\hline
\end{tabular}

\section{CONCLUSIONS}

1. Treated industrial wastewater effluents from petroleum crude oil refinery can be used for irrigating Gerbera jamesonii under protected ambient conditions without loss of quality and growth.

2. There was no significant effect for irrigation using treated industrial wastewater effluent or Nile river water and tap water concerning the 
number and quality of flowers harvested, during the first or the second agricultural seasons.

\section{REFERENCES}

A.O.A.C. (1990): Official Methods of Analysis of Association of Official Analytical Chemists. Pub. A.O.A.C. INC. USA Fifteenth Ed.; pp: 62-63, 236 and 877-878.

Abdin A.E., Gafaar I, (2009) Egyptian Water Policies towards Increasing its Value, MELIA workshop, Istanbul 21-23 March.

APHA (1998) Standard Methods for the Examination of Water and Wastewater, 20thed, American Public Health Association, Washington, DC, New York:

ASTM D 1067 (2011), American Standard Test Methods, Standard Test Methods for Acidity or Alkalinity of Water.

ASTM D 1293 (2012), American Standard Test Methods, Standard Test Methods for $\mathrm{pH}$ of Water.

ASTM D- 1429 (2013), American Standard Test Methods, Standard Test Methods for Specific Gravity of Water and Brine.

ASTM D 4972 (2013), American Standard Test Methods, Standard Test Method for $\mathrm{pH}$ of Soils.

ASTM D-1126 (2012), American Standard Test Methods, Standard Test Method for Hardness in Water.

ASTM D-4327 (2011), American Standard Test Methods, Standard Test Method for Anions in Water by Suppressed Ion Chromatography.

ASTM D4691 (2011), American Standard Test Methods, Standard Practice for Measuring Elements in Water by Flame Atomic Absorption Spectrophotometry.

ASTM D-6919 (2009), American Standard Test Methods, Standard Test Method for Determination of Dissolved Alkali and Alkaline Earth Cations and Ammonium in Water by Ion Chromatography. 
ASTM D-5907 (2013), American Standard Test Methods, Standard Test Methods for Filterable Matter (Total Dissolved Solids) and Nonfilterable Matter (Total Suspended Solids) in Water.

ASTMD-1125 (2014) American Standard Test Methods, Standard Test Methods for Electrical Conductivity and Resistivity of Water.

Baruah, T.C. and H.P. Barthakur. (Eds). (1997), A Textbook of Soil Analysis. Vikas Publishing, PVTLTD, New Delhi.

Black, C.A. 1982. "Methods of Soil Analysis. 2nd (Ed) Part 2. Chemical and Microbiological Properties "Am. Sco. Agron. Madison, Wisc, USA.

Cardoso, J.C. and Silva, J.A.T. (2013), Gerbera Micropropagation. Biotechnology Advances, Rehovot, 31, (8), 1344-1357.

Das C., Shammy F.H., Habiba S.U., Islam M.S. and Jamal Uddin A.F.M. (2012) Growth and Yield Performance of Exotic Potted Gerbera Cultivars (Gerbera jamesonii L.) in Bangladesh, Bangladesh Research Publications Journal, 7, (1), 16-20.

Darwish, M. R.; El Awar, F. A.; Sharara, M.; Hamdar, B. (1999) Economic environmental approach for optimum wastewater utilization in irrigation: A case study in Lebanon. Applied Engineering in Agriculture, 15, (1), 41-48.

Dobson, R. S. and Burgess J. E. (2007). Biological treatment of precious metal refinery wastewater: A review ; Minerals Engineering 20, $519-532$.

Francielly Torres Dos Santos ; Fernanda Ludwig ; Luiz Antonio De Mendonça Costa and Mônica Sarolli Silva De Mendonça (2015) Costa Nutrition and Growth of Potted Gerbera According To Mineral And Organic Fertilizer, Ornamental Horticulture 21 (2), 251-258.

Friedman, H.; Bernstein, N.; Bruner, M.; Rota, I.; Ben-Noon, Z؛. Zuriel, A.; Zuriel, R.; Finkelstein, S.; Umiel, N.; Hagiladi, A. (2007) Application of secondary treated effluents for cultivation of sunflower (Helianthus annuus L.) and celosia (Celosia argentea L) as cut flowers. Scientia Horticulturae, 115, (1), 62-69. 
Gomez, K. A. and Gomez, A. A.: (1984), Statistical Procedures for Agricultural Research, JohnWiley \& Sons, New York

Ishak, S., Malakahmad, A., and Isa, M.H., (2012) Refinery Wastewater Biological Treatment: A short Review. Journal of Scientific \& Industrial Research, 71, 251-256.

Jackson, M.L. (1973). Soil Chemical Analysis. Prentice-Hall of Indian Private, New Delhi.

Keditsu R. Gerbera: (2013) Soil Fertility and Plant Nutrition, Scientific Journal of Agricultural 2(3) 97-114.

Lisânea M.O. Damasceno, Aderson S. Andrade Júnior, Hans R.Gheyi,Valdenir Q. Ribeiro, (2008) Treated wastewater application via trickle irrigation onto Gerbera crop in teresina, state piauí, Brazil, CIGR - International conference of agricultural engineering xxxvii congresso brasileiro de engenharia agrícola Conbea, Brazil, 31 August to 4 September, 2008.

Lisânea M.O. Damasceno, Aderson S. Andrade Júnior, Hans R.Gheyi, Valdenir Q. Ribeiro, (2008), Growth of fertilized gerbera with treated domestic effluents in teresina, pi, Brazil1, CIGR International conference of agricultural engineering xxxvii congresso brasileiro de engenharia agrícola - Conbea, Brazil, 31 August to 4 September, 2008.

Lisânea M. O. Damasceno, Aderson S. de Andrade Júnior, Hans R. Gheyi4, Valdenir Q. Ribeiro \& Nildo da S. Dias, (2010), Cultivation of Gerbera irrigated with treated domestic effluents, R. Bras. Eng. Agríc. Ambiental, 14, (6), 582-588.

Loser, H. (1986), New gerbera cultivars at Heidelberg. Deutscher Gartenbau, 40 (32),1461-1464.

Mehraj H., Taufique T., Ona A.F., Nusrat A. and Jamal Uddin A.F.M, (2014) Performance of Gerbera cultivars under different wavelengths of solar spectrum, Journal of Bangladesh Academy of Sciences, 38, (1), 27-37. 
Nungki Perme ,Swarnali Nath Choudhury, Ratna Choudhury, Taking Natung1 and Biplab De, (2015) Medicinal plants in traditional use at Arunachal Pradesh, India, International Journal of Phytopharmacy, 5 (5),86-98.

Papadopoulos, I.; Chimonidou, D.; Savides, S; Polycarpo, P. (2005) Optimization of irrigation with treated wastewater on flower cultivations. In: Workshop Non-Conventional Water Use WASAMED project. Cairo. 2005 pages 227-235.

Soliman G.S., Abdel-Azeem A. M. and Salem F.M.: (2012) Egypt's Water Warriors: Water Pollution in Egypt and the Role of NGOs in Reaching Integrated Management. BALWOIS - Ohrid, Republic of Macedonia - 28 May, 2 June 2012.

Srivastava RC and Adi Community, (2009), Traditional knowledge of Adi tribe of Arunachal Pradesh on Plants, Indian Journal of Traditional knowledge, 8 (2), 41-46.

Sujatha, K., Gowda, J.V.N. and Khan M.M. (2002). Effects of different fertigation levels on gerbera under low cost greenhouse. J. Orn. Hort., New Series 5(1), 54-59. 


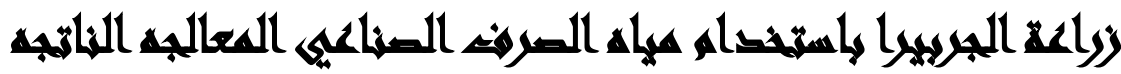

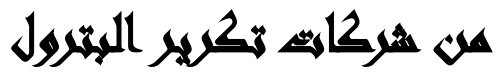

[६]

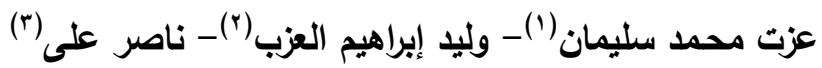

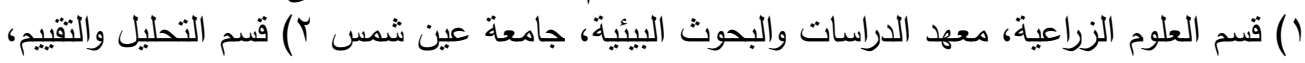

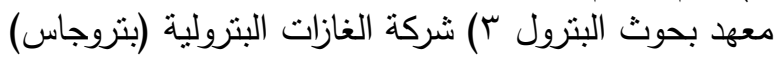

\section{(ling}

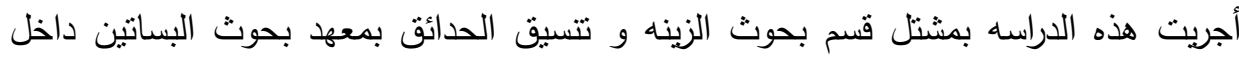

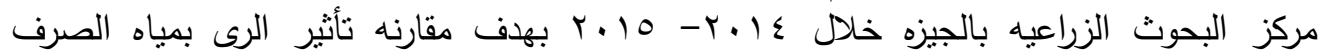

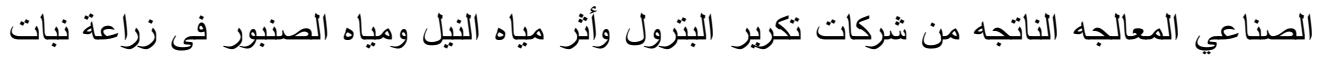

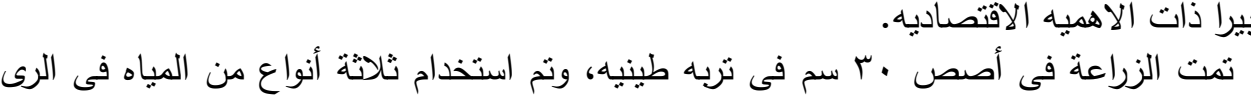

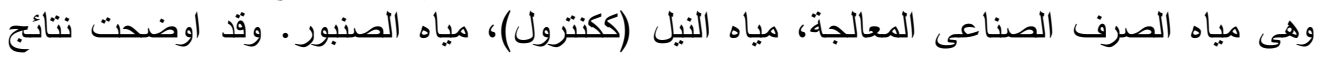



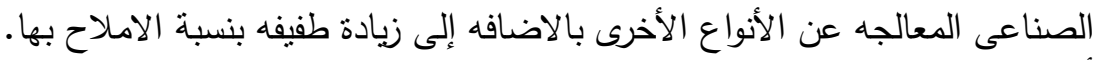

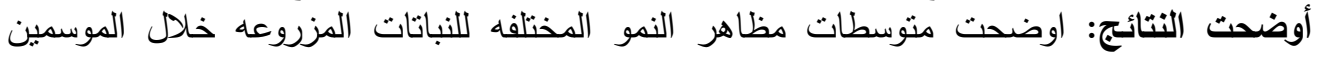

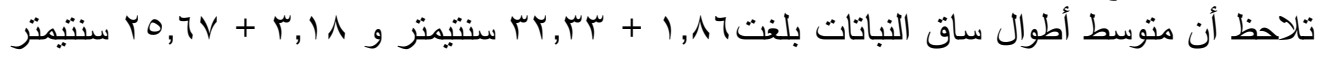

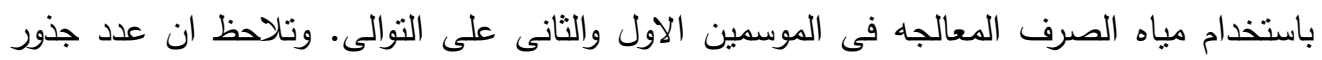

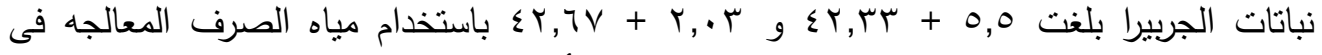

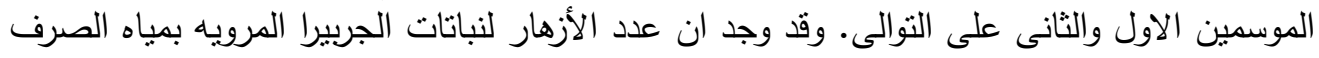

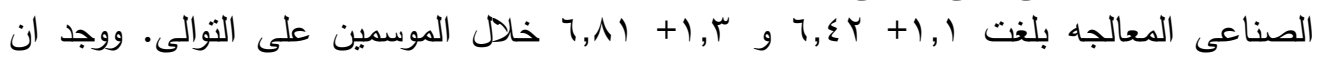

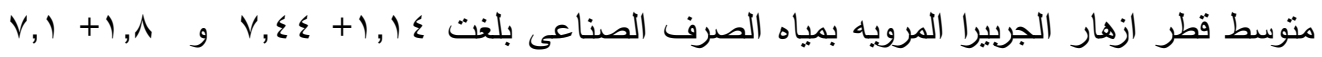

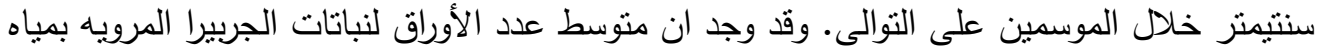

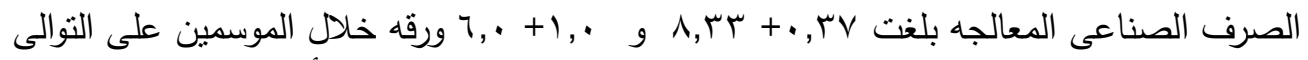

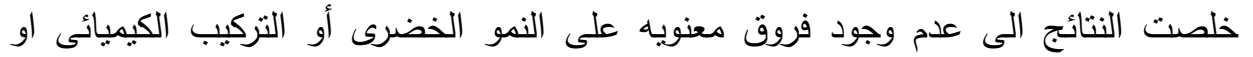

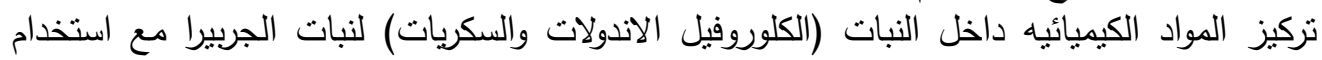

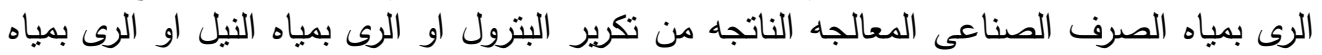

الصنبور 